concentration, with the assumption that an inspired oxygen concentration of $24 \%$ equates to $2 \mathrm{l} / \mathrm{min}$; concentrations of $24 \%-35 \%$ with $2 \mathrm{l} / \mathrm{min}$ have been described. $^{5}$

The prescription of oxygen is complex, and a drug Kardex does not accommodate the precise details required for the variety of delivery devices. This was clearly shown in the second audit, where the accuracy of the prescription was greater with the chart than with the drug Kardex. We have shown that a specific prescription chart for oxygen improved clinical practice in our specialist medical respiratory centre, and we recommend the use of such a chart.

Contributors: MED designed the study, analysed and interpreted the results, and wrote the paper. FK and $\mathrm{AD}$ analysed and interpreted the data. JCGS designed the study and the chart. AKW and CSH critically revised the paper. RMcLN designed the study and the chart and critically revised the paper.

Competing interests: None declared.

1 British National Formulary 1999;37:153.

2 Bateman NT, Leach RM. ABC of oxygen. Acute oxygen therapy. BMJ 1998;317:798-801.

3 Small D, Duha A, Wieskopf B, Dajczman E, Laporta D, Kreisman H, et al. Uses and misuses of oxygen in hospitalised patients. Am J Med 1992;92:591-5.
The North West Lung Centre Oxygen Prescription Chart

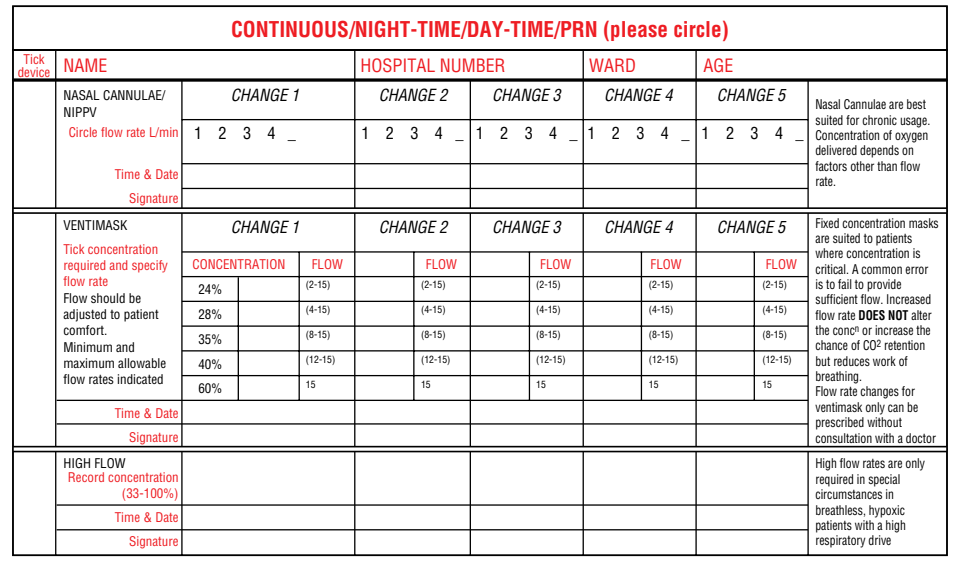

Prescription chart for oxygen introduced after first audit

4 Davies RJO, Hopkin JM. Nasal oxygen in exacerbations of ventilatory failure: an underappreciated risk. BMJ 1989;299:43-4

5 Bazuaye EA, Stone TN, Corris PA, Gibson GJ. Variabilty of inspired oxygen concentration with nasal cannulas. Thorax 1992;47:609-11.

(Accepted 11 May 2000)

\title{
Refused and granted requests for euthanasia and assisted suicide in the Netherlands: interview study with structured questionnaire
}

\author{
Ilinka Haverkate, Bregje D Onwuteaka-Philipsen, Agnes van der Heide, Piet J Kostense, \\ Gerrit van der Wal, Paul J van der Maas
}

In 1995, physicians in the Netherlands received 9700 explicit requests for euthanasia or physician assisted suicide, of which $37 \%$ were granted and carried out. ${ }^{1}$ Among the remaining requests, about half were refused by the physician; in the rest of the cases either the physician's promise of help could be effected, or the patient withdrew the request. ${ }^{2}$ Knowledge of specific characteristics of refused and granted requests for euthanasia or physician assisted suicide may give insight into physicians' decision making and into the role of criteria for prudent practice. We therefore compared the characteristics of refused and granted requests.

\section{Subjects, methods, and results}

In 1995 and 1996, 405 Dutch physicians, randomly sampled nationwide and stratified by specialty and region, were interviewed by over 30 specifically trained and experienced physicians using a structured questionnaire. The response rate was $89 \%$. Euthanasia was defined as the administration of drugs with the explicit intention of ending the patient's life, at the patient's explicit request. Assisted suicide was defined as the prescribing or supplying of drugs with the explicit intention of enabling the patient to end his or the patient died before a decision had been reached or her own life. All physicians were asked to describe their most recent case of a granted request (134 physicians had had such a case) and their most recent case of a refused request (148 physicians had had such a case).

Patients whose requests were refused, compared with patients whose requests were granted, were more often female and aged over 80; were less likely to have cancer; were more likely to have depression as a predominant complaint; were more likely to have a remaining life span of over six months; were less likely to have made a highly explicit request; were less likely to be competent; were less likely to be suffering utterly "hopelessly and unbearably," and were more likely to have access to alternatives for treatment (table).

In both the refused and the granted requests "avoiding loss of dignity" (42\% (95\% confidence interval $31.6 \%$ to $52.4 \%)$ and $56 \%(46.3 \%$ to $66.2 \%)$ respectively) and "unbearable or hopeless suffering" $(39 \%(29.0 \%$ to $48.8 \%)$ and $74 \%(64.9 \%$ to $82.6 \%))$ were most often mentioned as the patient's reason for requesting euthanasia or physican assisted suicide. Only two reasons were mentioned more often in refused requests than in granted requests: "weariness of life" $(40 \%(29.8 \%$ to $50.5 \%)$ and $18 \%(10.2 \%$ to $25.5 \%)$ respectively) and "not wanting to become

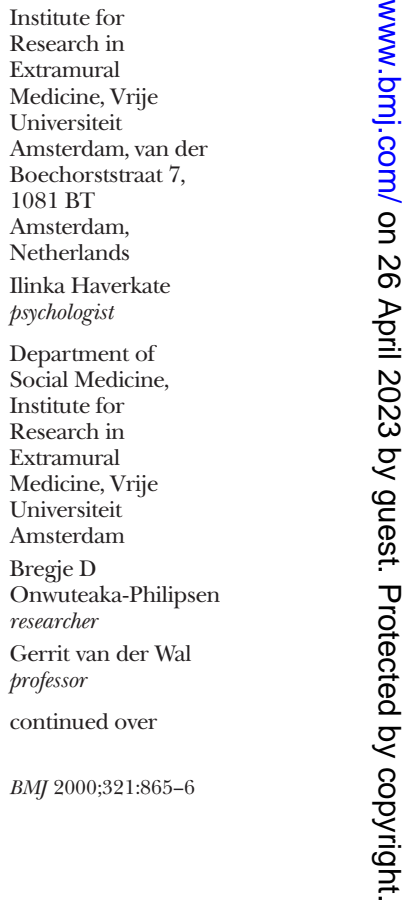

BMJ VOLUME 3217 OCTOBER 2000 bmj.com 
Department of

Public Health,

Erasmus University

Rotterdam, PO Box

$1738,3000 \mathrm{DK}$

Rotterdam,

Netherlands

Agnes van der

Heide

epidemiologist

Paul J van der Maas

professor

Department of

Epidemiology and

Biostatistics,

Institute for

Research in

Extramural

Medicine, Vrije

Universiteit

Amsterdam

Piet J Kostense

statistician

Correspondence to:

I Haverkate

I.Haverkate.gpnh@

med.vu.nl
Characteristics of most recent cases of refused and granted requests for euthanasia or physician assisted suicide. Values are weighted, rounded percentages ( $95 \%$ confidence intervals), extrapolated to all physicians in the Netherlands*

\begin{tabular}{|c|c|c|}
\hline & $\begin{array}{l}\text { Refused requests } \\
\quad(n=148)\end{array}$ & $\begin{array}{l}\text { Granted requests } \\
\quad(n=134)\end{array}$ \\
\hline \multicolumn{3}{|l|}{ Patient's characteristics } \\
\hline Female & 53 (43.4 to 63.2$)$ & $40(30.5$ to 50.2$)$ \\
\hline \multicolumn{3}{|l|}{ Age (years): } \\
\hline $0-49$ & 13 (7.4 to 20.4$)$ & 21 (12.6 to 29.1$)$ \\
\hline $50-64$ & 18 (9.8 to 25.1$)$ & 28 (18.7 to 36.7$)$ \\
\hline $65-79$ & 45 (34.3 to 55.3$)$ & 43 (32.8 to 52.6$)$ \\
\hline$\geqslant 80$ & $24(14.8$ to 33.0$)$ & $9(3.1$ to 14.5$)$ \\
\hline \multicolumn{3}{|l|}{ Diagnosis: } \\
\hline Cancer & $43(32.2$ to 52.9$)$ & 86 (78.4 to 92.6$)$ \\
\hline Cardiovascular disease & $6 \dagger$ & $2 \dagger$ \\
\hline Disease of the nervous system & $16(9.4$ to 22.0$)$ & $5 \dagger$ \\
\hline $\begin{array}{l}\text { Disease of the respiratory } \\
\text { system }\end{array}$ & $10(2.8$ to 16.2$)$ & $2 \dagger$ \\
\hline Psychiatric disorders & 13 (5.8 to 21.9 ) & 0 \\
\hline Other & 13 (6.5 to 19.8$)$ & $7(0.2$ to 13.0$)$ \\
\hline $\begin{array}{l}\text { Depression was a predominant } \\
\text { complaint }\end{array}$ & 39 (28.9 to 49.7$)$ & $3(0.2$ to 5.0$)$ \\
\hline \multicolumn{3}{|l|}{ Shortening of life: } \\
\hline$>6$ months & 41 (30.7 to 51.4$)$ & $5(0.4$ to 8.6$)$ \\
\hline 1-6 months & 24 (14.9 to 33.2$)$ & $22(14.2$ to 30.1$)$ \\
\hline 1-4 weeks & 15 (7.8 to 22.8$)$ & 45 (34.7 to 54.6$)$ \\
\hline$<1$ week & 16 (8.2 to 24.6$)$ & $18(10.0$ to 25.6$)$ \\
\hline$<24$ hours & $2 \dagger$ & $8(2.5$ to 14.4$)$ \\
\hline No shortening of life & $1 \dagger$ & $2 \dagger$ \\
\hline
\end{tabular}

Requirements for prudent practice

Patient's request:

\begin{tabular}{|c|c|c|}
\hline Highly explicit & 75 (66.2 to 83.9$)$ & $97 \dagger$ \\
\hline Fairly explicit & 25 (16.1 to 33.8) & $3 \dagger$ \\
\hline $\begin{array}{l}\text { Patient's request entirely } \\
\text { voluntary }\end{array}$ & 80 (72.0 to 88.1$)$ & $98 \dagger$ \\
\hline Patient was competent & 62 (51.5 to 72.3 ) & $100 t$ \\
\hline \multicolumn{3}{|l|}{ Unbearable suffering: } \\
\hline Utterly & 11 (4.6 to 18.3$)$ & 58 (48.0 to 67.7$)$ \\
\hline To a high degree & 19 (10.9 to 26.8$)$ & 25 (16.3 to 33.4$)$ \\
\hline To a lower degree & 70 (60.2 to 79.3$)$ & 17 (9.7 to 25.0$)$ \\
\hline \multicolumn{3}{|l|}{ Hopeless suffering: } \\
\hline Utterly & 29 (19.3 to 38.2) & 81 (72.3 to 88.6$)$ \\
\hline To a high degree & 23 (13.9 to 31.8) & 14 (6.8 to 21.3) \\
\hline To a lower degree & 48 (37.8 to 59.0) & $5 \dagger$ \\
\hline $\begin{array}{l}\text { Alternatives for treatment } \\
\text { available }\end{array}$ & 50 (39.8 to 60.9) & 17 (10.0 to 24.2$)$ \\
\hline Written will & 35 (24.4 to 44.8$)$ & 70 (60.4 to 80.4$)$ \\
\hline $\begin{array}{l}\text { Consultation of another physician } \\
\text { took place }\end{array}$ & 16 (8.0 to 23.9 ) & 79 (71.7 to 88.0$)$ \\
\hline
\end{tabular}

took place

${ }^{*}$ To extrapolate our findings to all physicians in the Netherlands, we calculated weights based on the percentage of the different types of physician represented in the sample and on the $13 \%$ of inpatient deaths that were attended by physicians of specialties not included in our sample; $95 \%$ confidence intervals were computed through direct standardisation using the normal approximation to the binomial distribution.

†Confidence intervals cannot be calculated.

a burden on the family" (23\% (14\% to $32.3 \%)$ v $13 \%$ $(5.8 \%$ to $19.2 \%))$. The most often mentioned reasons given by physicians for refusing the request were "suffering was not unbearable" (35\%); "still alternatives for treatment" (32\%); "the patient was depressed or had psychiatric symptoms" (31\%); and "the request was not well considered" (19\%) (data not shown).

\section{Comment}

Requests for euthanasia and physician assisted suicide that are refused have several characteristics not shared by granted requests. The criteria for prudent practice, which are supposed to guide physicians in their decision making, are more often met in granted requests than in refused requests. In particular, the availability of alternatives for treatment and the incompetence and depression of the patient seem to play an important part in refusals. The findings seem to show that, compared with patients whose requests are granted, patients whose requests are refused have more mental health problems and are less likely to be clearly in the terminal phase. Studies in the United States have shown that patients with depression are more inclined than patients without depression to request physician assisted suicide. ${ }^{34}$ Whether this is the case in the Netherlands is not known.

Contributors: GvdW and PJvdM initiated the research. All authors contributed to the development of the study. IH and BDO-P coordinated the interviews. IH carried out data analyses and wrote the paper. BDO-P helped with data analyses and edited the paper. PJK gave statistical advice and calculated the $95 \%$ confidence intervals. All authors participated in interpreting the data and in writing and editing the paper.

Funding: The study was supported by a grant from the Dutch Ministry of Justice and Health, Welfare, and Sports.

Competing interests: None declared.

1 Van der Maas PJ, van der Wal G, Haverkate I, de Graaff CLM, Kester JGC, Onwuteaka-Philipsen BD, et al. Euthanasia, physician-assisted suicide, and other medical practices involving the end of life in the Netherlands, 1990-1995. N Engl J Med 1996;335:1699-705.

2 Van der Wal PJ, van der Maas PJ. Euthanasia and other medical decisions concerning the end of life. Practice and notification procedure. SDU Publishers: The Hague, 1996. [In Dutch.]

3 Breitbart W, Rosenfeld BD, Passik SD. Interest in physician-assisted suicide among ambulatory HIV-infected patients. Am I Psychiatry 1996;153:238-42.

4 Emanuel EJ, Fairclough DL, Daniels ER, Clarridge BR. Euthanasia and physician-assisted suicide: attitudes and experiences of oncology patients, oncologists, and the public. Lancet 1996;347:1805-10.

(Accepted 14 April 2000)

\section{Endpiece \\ “Old Man" (after Marot)}

Alexander Pushkin (1799-1837), Russia's greatest poet, wrote this poem when he was 15 while he was at the lyceum in Tsarkoe Selo. He linked it to Clement Marot (1496-1544), a French poet known for his light and graceful lyrics. Pushkin had an unhappy love life and died from wounds received in a duel over his wife's infidelity.

I am no more the ardent lover

Who caused the world such vast amaze:

My spring is past, my summer over,

And dead the fires of other days.

Oh, Eros, god of youth! Your servant

Was loyal-that you will avow.

Could I be born again this moment,

Ah, with what zest l'd serve you know!

(Translated by Babette Deutsch)

The Poems, Prose and Plays of Alexander Pushkin, edited by Avrahm Yarmolinsky. New York: The Modern Library, Randon House, 1964.

Submitted by Fred Charatan, retired geriatric physician, Florida 